\title{
Weaning marginally affects glucose transporter (GLUT4) expression in calf muscles and adipose tissues
}

\author{
BY JEAN-FRANÇOIS HOCQUETTE ${ }^{1}$, CAROLE CASTIGLIA-DELAVAUD ${ }^{1}$, \\ BENOÎT GRAULET ${ }^{1}$, PASCAL FERRE ${ }^{2} *$, BRIGITTE PICARD ${ }^{1}$ \\ AND MICHEL VERMOREL ${ }^{1}$ \\ ${ }^{1}$ INRA, Laboratoire Croissance et Métabolismes des Herbivores, Theix, 63122 Saint-Genès-Champanelle, \\ France \\ ${ }^{2}$ INSERM U342, Hôpital Saint Vincent de Paul, 75014 Paris, France
}

(Received 16 October 1996-Revised 2 January 1997-Accepted 9 January 1997)

\begin{abstract}
The nutritional regulation of glucose transporter GLUT4 was studied in eight muscles and four adipose tissues from two groups of preruminant (PR) or ruminant $(R)$ calves of similar age $(170 \mathrm{~d})$, empty body weight $(194 \mathrm{~kg})$ at slaughter, and level of net energy intake from birth onwards. Isocitrate dehydrogenase (EC 1.1.1.41) activity in muscles was not different between $P R$ and $R$ except in masseter muscle from the cheek $(+71 \%$ in $R ; P<0.003)$, which becomes almost constantly active at weaning for food chewing. Basal and maximally-insulin-stimulated glucose transport rate (GTR) per $\mathrm{g}$ tissue wet weight in rectus abdominis muscle were significantly higher in $\mathbf{R}$ calves $(+31$ and $41 \%$ respectively; $P<0.05$ ). GLUT4 protein contents did not differ in muscles from $P R$ and $R$ except in masseter $(+74 \%$ in $R ; P<0.05)$ indicating that the increased GTR in rectus abdominis cannot be accounted for by an enhanced GLUT4 expression. GLUT4 mRNA levels did not differ between the two groups of animals in all muscles suggesting a regulation of GLUT4 at the protein level in masseter. GLUT4 number expressed on a per cell basis was lower in adipose tissue from $R$ calves $(-39 \% ; P<0.05)$ and higher in internal than in peripheral adipose tissues. In summary, the regulation of GLUT4 in calves at weaning differs markedly from that previously described in rodents (for review, see Girard et al. 1992). Furthermore, significant inter-individual variations were shown for metabolic activities in muscle and for biochemical variables in adipose tissue.
\end{abstract}

Glucose transport rate: Glucose transporter expression: Insulin-sensitive tissues

The suckling-weaning transition is characterized by profound changes in nutrition which in turn induce metabolic adaptations of glucose metabolism. For instance, in rats at weaning, the fat-rich milk is gradually replaced by the high-carbohydrate diet of the adult. This is associated with an enhanced overall insulin responsiveness of glucose utilization and of glucose transport rate (GTR) in adipose tissue and skeletal muscles (for review, see Girard et al. 1992), the latter being the rate-limiting step of glucose utilization (for review, see Kahn 1992; Hocquette et al. 1996a). These regulatory changes are related to an increased expression of the insulin-regulatable glucose transporter (GLUT4) in muscles and adipose tissues (for review, see Girard et al. 1992).

The changes in nutrition at weaning differ markedly between rodents and ruminants. Indeed, unlike the rat, the contribution of carbohydrates to total nutrition decreases from $35-45 \%$ of total energy absorption to less than $5 \%$ as calves become ruminant. However, much less is known about the regulation of glucose metabolism in bovines than in rats at

* Present address: INSERM U465, Centre Biomédical des Cordeliers, 75270 Paris Cedex 06, France. 
weaning. This lack of knowledge results in part from the lack of available information about the regulation of glucose utilization and transport in large species such as cattle, and also from the limited information on glucose transporters in ruminants (for review, see Hocquette et al. 1996a). Nevertheless, it is well known that young suckling calves (Kouame et al. 1984) or calves fed on milk-substitutes (Doppenberg \& Palmquist, 1991) have higher levels of circulating blood glucose and insulin than ruminant $(R)$ animals, and it has been previously reported that glucose clearance rate in vivo was higher in $\mathrm{R}$ calves than in milk-fed calves at least in the postprandial state (Palmquist $e$ t al. 1992).

We have previously described a method to measure GTR into incubated fibre strips of bovine muscle (Hocquette et al. 1995) similar to that used in human subjects (for review, see Zierath, 1995), and we have also demonstrated that GLUT4 was expressed in bovine muscles and adipose tissues at both the protein (Hocquette et al. 1995) and the mRNA levels (Hocquette et al. 1996b). However, direct comparison of GTR in preruminant (PR) or $\mathrm{R}$ calves had never been reported. The aim of the present study, therefore, was to investigate the regulation of glucose transport and glucose transporter expression at weaning in bovine tissues. We thus examined the expression of GLUT4 in muscles from $P R$ and $R$ calves in relation to putative variations in GTR in the muscle tissue. In addition, the expression of GLUT4 was also studied in four adipose tissues in the same PR and R calves.

\section{MATERIALS AND METHODS}

\section{Reagents}

A polyclonal antibody raised against rat GLUT4 was supplied by East-Acres Biologicals (Southbridge, MA, USA). The synthetic peptide, to which the antibody was raised, was prepared by Neosystem Laboratoire (Strasbourg, France). Endoglycosidase F-N-glycosidase $\mathrm{F}$ was obtained from Boehringer-Mannheim (Meylan, France). The chemicals for immunoblotting were supplied by Bio-Rad (Munich, Germany), except membranes (Immobilon-P) which were obtained from Millipore (Bedford, MA, USA). ${ }^{125}$ I-labelled protein $\mathrm{A}(>1.1 \mathrm{GBq} / \mathrm{mg})$, ECL Western blotting kit and Hyperfilms MP were supplied by Amersham International (Amersham, Bucks.). 2-Deoxy[1,2- $\left.{ }^{3} \mathrm{H}\right]$ glucose $(970 \mathrm{GBq} / \mathrm{mmol}$ ) was purchased from New England Nuclear Life Science Products (Boston, MA, USA). $\left[\mathrm{U}-{ }^{14} \mathrm{C}\right]$ sucrose $(20 \mathrm{GBq} / \mathrm{mmol}), \quad\left[\alpha-{ }^{32} \mathrm{P}\right] \mathrm{dCTP} \quad(>111 \mathrm{TBq} / \mathrm{mmol})$ and $\left[\gamma^{32} \mathrm{P}\right] \mathrm{dATP}$ ( $>111 \mathrm{TBq} / \mathrm{mmol}$ ) were purchased from ICN Biochemicals (Irvine, CA, USA). Guanidium thiocyanate was obtained from Fluka (Ronkonkoma, NY, USA). Genescreen membranes were obtained from New England Nuclear Life Science Products. T4 polynucleotide kinase was supplied by New England Biolabs Inc. (Beverly, MA, USA). Saturated phenol, chloroform-isoamyl alcohol $(49: 1, \mathrm{v} / \mathrm{v})$, agarose and nonaprimer labelling kit with reagents for probe purification were purchased from Appligène (Illkirch, France). RNA molecular-weight markers were from Bethesda Research Laboratories (Bethesda, MD, USA). Other reagents were from Sigma (St Louis, MO, USA).

\section{Animals and experimental design}

Fourteen Montbéliard male calves, tied and housed in individual stalls in a room with natural lighting were used. Two homogeneous groups were formed at the age of $88 \mathrm{~d}$ on the basis of live weight, average daily weight gain and average nutritional efficiency. From birth to $107 \mathrm{~d}$ of age, animals were maintained on a standard milk-substitute according to a 
feeding pattern designed to allow an average daily weight gain of $1000 \mathrm{~g}$. From $107 \mathrm{~d}$ to slaughter, PR calves of the first group were fed individually on a commercial milksubstitute containing approximately (g/kg DM) 200 fat, 550 carbohydrates and 250 protein. The amount of lactose in this diet was higher than that in classical milk-substitutes for vealcalf production in France in order to exacerbate the differences in dietary carbohydrate supply between the two groups of calves. Animals in the second group were progressively weaned from 107 to $128 \mathrm{~d}$ of age and became $\mathrm{R}$ calves. These calves were fed individually on a mixed diet composed of $(\mathrm{g} / \mathrm{kg}) 800$ concentrate and 200 hay, according to a feeding pattern designed to allow an average daily gain of $1300 \mathrm{~g}$. Composition $(\mathrm{g} / \mathrm{kg})$ of the concentrate was: 300 dehydrated lucerne (Medicago sativa), 400 sugarbeet pulp, 140 barley, 110 soyabean meal and 50 mineral compound. The concentrate contained $(\mathrm{g} / \mathrm{kg})$ 162 protein and 18 fat. Body weight was measured weekly and the rate of feeding was adjusted accordingly so that net energy intake from birth onwards was similar for the two groups of animals.

Calves were slaughtered at $170 \mathrm{~d}$ of age (Picard et al. 1995). Slaughtering was done at 09.00 hours after an overnight fast by stunning (captive-bolt pistol) and exsanguination. Tissue samples $(50-100 \mathrm{~g})$ from the following muscles were always taken at the same site for all animals to minimize sampling error (Johnson et al. 1973; Hocquette et al. 1995): heart $(\mathrm{H})$, masseter (MA) diaphragma (D), musculus rectus abdominis (RA), musculus longissimus dorsi (LD) at the level of the 6th rib, musculus semitendinosus (ST) from the medial portion, musculus tensor fasciae latae (TFL), musculus cutaneus trunci (CT) from the thick part, perirenal adipose tissue (PAT), intermuscular adipose tissue (IMAT), omental adipose tissue (OAT) and subcutaneous adipose tissue (SCAT).

Samples from calf muscles were quickly trimmed of visible fat and connective tissue. Then, samples of muscles or white adipose tissues were cut into pieces, which were then divided into two parts as soon as they were obtained. One part (six to seven small pieces within the sample) was immediately homogenized at $4^{\circ}$ in buffer containing peptidase inhibitors (chymostatin, pepstatin $\mathrm{A}$, leupeptin, antipain $(5 \mu \mathrm{g} / \mathrm{ml}$ each), aprotinin $(0.17$ trypsin inhibitor units/ml) and $1 \mathrm{mM}$-phenylmethylsulphonyl fluoride which was added extemporaneously) as previously described (Hocquette et al. 1995). The second part was frozen in less than $10 \mathrm{~min}$ post exsanguination in liquid $\mathrm{N}_{2}$ and stored at $-80^{\circ}$ for subsequent analyses. Samples were always pulverized in liquid $\mathrm{N}_{2}$ to obtain an homogeneous powder before any treatment in order to avoid any problem of sampling error.

\section{2-Deoxyglucose transport}

A sample of muscle RA was taken with a $30 \mathrm{~mm}$ clamp from each calf at slaughter. Six muscle-fibre strips weighing 70-120 mg were isolated from each mounted muscle sample in less than $10 \mathrm{~min}$. The rest of the sample was frozen in liquid $\mathrm{N}_{2}$ or homogenized as described previously for other analyses. The muscle strips were incubated in $4.4 \mathrm{ml}$ oxygenated Krebs-Henseleit buffer containing $2 \mathrm{mM}$-pyruvate and $5 \mathrm{mM}$-2-deoxy $\left[1,2-{ }^{3} \mathrm{H}\right]-$ glucose $(18.5 \mathrm{kBq} / \mathrm{ml})$. Basal and maximally-stimulated GTR measurement was performed without or with insulin $\left(10^{-6} \mathrm{M}\right)$ respectively (Hocquette et al. 1995). Preliminary experiments showed that maximal stimulation of GTR was observed beyond $10^{-8} \mathrm{M}$ insulin (data not shown). Tissue concentrations of labelled 2-deoxyglucose and 2deoxyglucose-6-phosphate were determined as previously described (Hocquette et al. 1995). 


\section{Analytical techniques}

Packed cell volume was measured after centrifugation of blood samples. Commercial kits were used to determine plasma insulin (INSIK-5 P2796; Sorin Biomedica, Saluggia, Italy) and glucose concentrations (PAP 250 ref 61271; BioMérieux, Marcy-l'Etoile, France). Protein and DNA contents in muscles and adipose tissues and activities of isocitrate dehydrogenase (EC 1.1.1.41; ICDH), characteristic of muscle oxidative metabolism, and of lactate dehydrogenase $(E C 1.1 .1 .27 ; \mathrm{LDH})$, characteristic of muscle glycolytic metabolism, were measured as previously described (Hocquette et al. 1995). Concentrations of volatile fatty acids in the rumen content of $\mathrm{R}$ calves were determined according to the method of Jouany (1982).

\section{Quantification of GLUT4 protein by immunoblotting}

Tissue samples homogenized in sucrose buffer containing peptidase inhibitors were used and crude membranes were prepared as described previously (Hocquette et al. 1995). In some experiments, crude membranes were treated with endoglycosidase $\mathrm{F}-\mathrm{N}$-glycosidase $\mathrm{F}$ for complete removal of the oligosaccharides on the proteins (Kaestner et al. 1991). Subcellular fractions were stored at $-80^{\circ}$ until required for immunoblot analyses (Hocquette et al. 1995). The samples were not routinely heated before electrophoresis but incubated at room temperature overnight in Laemmli buffer containing 2-mercaptoethanol $(50 \mathrm{ml} / \mathrm{l})$ to avoid the formation of aggregates. Samples were then subjected to SDS-PAGE ( $12 \%$ gels). Immunoblot was performed using polyclonal antibody against rat GLUT4 and using ${ }^{25}$ I-labelled protein A or a horseradish peroxidase (EC 1.11.1.7)-linked anti-rabbit immunoglobulin detected by a chemiluminescent reaction (ECL Western blotting kit). To test the specificity of the detected bands, the blots were incubated either with a nonimmune serum or with diluted immune serum in the presence of the peptide $(0.5 \mu \mathrm{g} / \mathrm{ml})$ to which the antibody was raised (Hocquette et al. 1996b). Hyperfilm MP were exposed to membranes, and GLUT4 amounts were quantified by scanning densitometry (Hoeffer, San Francisco, CA, USA) of the autoradiograms (Hocquette et al. 1995).

\section{Quantification of MRNA coding for GLUT4}

Total RNA were isolated as previously described (Hocquette et al. 1996b). The concentration of RNA was determined by absorbance at $260 \mathrm{~nm}$. All samples had a $260: 280 \mathrm{~nm}$ absorbance ratio of approximately $2 \cdot 0$. The RNA samples were stored precipitated by 0.1 vol. sodium acetate $(2 \mathrm{M}, \mathrm{pH} 5.0)$ and 2.5 vol. ethanol until required for use. For Northern analyses, RNA portions $(40 \mu \mathrm{g})$ were washed by diethylpyrocarbonatetreated water $(250 \mathrm{ml} / \mathrm{l})$ and ethanol $(750 \mathrm{ml} / 1)$, then denatured in a solution containing 2.2 M-formaldehyde and formamide $(500 \mathrm{ml} / \mathrm{l})$ by heating at $65^{\circ}$ for $10 \mathrm{~min}$, size fractionated by $1.5 \%$ agarose gel electrophoresis, and electrophoretically transferred to Genescreen membranes. The integrity of RNA was assessed by ethidium bromide staining before transfer. The bovine GLUT4 probe previously cloned in our laboratory (Hocquette et al. $1996 b$ ) was labelled by random priming with ${ }^{32} \mathrm{P}$ and free nucleotides removed using the nonaprimer labelling kit (Appligène, Illkirch, France) following the recommendations of the suppliers. Prehybridizations and hybridizations to the GLUT4 probe were performed at $42^{\circ}$ for $2-4 \mathrm{~h}$ and $16-20 \mathrm{~h}$ respectively in solutions containing deionized formamide $(450 \mathrm{ml} / 1)$. The membranes were washed twice for $5 \mathrm{~min}$ in twice the standard concentration of saline-sodium phosphate-EDTA buffer (SSPE) at room temperature 
(standard SSPE $0.15 \mathrm{M}-\mathrm{NaCl}, 10 \mathrm{M}-\mathrm{NaH}_{2} \mathrm{PO}_{4}$ (pH 7.4) and $1 \mathrm{mM}-\mathrm{EDTA}$ ), once for $30 \mathrm{~min}$ in twice the standard concentration of SSPE containing SDS $(20 \mathrm{ml} / 1)$ at $55^{\circ}$, once for $15 \mathrm{~min}$ in standard SSPE containing SDS $(20 \mathrm{ml} / 1)$ at $55^{\circ}$ and once for $15 \mathrm{~min}$ in tenfold dilution of standard SSPE containing SDS $(20 \mathrm{ml} / 1)$ at $55^{\circ}$. The membranes were exposed to Hyperfilm MP for $2-10 \mathrm{~d}$ at $-80^{\circ}$ with two intensifying screens. Quantification was performed using scanning densitometry (Hoeffer, San Francisco, CA, USA). Results were corrected for variations in the amount of RNA loaded by using values of hybridization to a 18S rRNA probe (Hocquette et al. 1996b).

\section{Statistical analyses}

ANOVA of the data was done using the GLM procedure of Statistical Analysis Systems (1987). For GTR, the effects tested in the model included group (G) of calves (PR, R), calf (C) nested within treatment group, insulin (I); i.e. absence or presence of insulin for basal and maximally-stimulated GTR respectively), and the interaction group $\times$ insulin $(\mathrm{G} \times \mathrm{I})$. For biochemical variables and GLUT4 protein contents in tissues, the effects tested in the model included $\mathrm{G}$ of calves (PR, R), C nested within groups, tissue (i.e. muscle (M) or adipose tissues $(A T))$ and the interaction group $\times$ tissue $(G \times M$ or $G \times A T)$. The $G$ factor was tested against $C$ within groups. The residual mean square was used as the error term for other effects. Results are expressed as means and standard errors of the means ( $\mathrm{SEM}=\sqrt{V}$; residual mean squares/number of observations per treatment). If a statistically significant difference was found among tissues, a paired Student's $t$ test was used to determine the site of significance. If a statistically significant difference was found among groups, a paired Student's $t$ test was used for comparisons between groups, tissue per tissue. $P<0.05$ was considered statistically significant for Student's $t$ tests.

\section{RESULTS}

\section{Experimental conditions and animal characteristics}

Body weight of the animals as well as average daily weight gain between 18 and $118 \mathrm{~d}$ of age (beginning of the experiment and mid period of weaning respectively) were similar for the two groups of PR or R calves (Table 1). However, average daily weight gain from $118 \mathrm{~d}$ of age onwards and live body weight at slaughter were higher for $\mathrm{R}$ calves than for PR calves because of a higher digesta content after weaning. Nevertheless, empty body weight at slaughter did not differ between the two groups of animals. Carcass weight tended to be lower for $\mathrm{R}$ than for PR calves $(-6 \% ; P<0 \cdot 10$; Table 1$)$.

According to the composition of the lactose-rich milk-substitute used in the present experiment, protein, carbohydrates and fat provided approximately 25,40 and $35 \%$ of absorbed energy respectively in PR calves. In contrast, in R calves, concentrate and hay are converted in the rumen into volatile fatty acids by micro-organisms. Therefore, protein, volatile fatty acids, fat and carbohydrates provided approximately $25,65-70,8$ and $2 \%$ of absorbed energy respectively, according to the composition of the diet and the estimations of Vermorel (1978). As the relative amounts of acetate and butyrate in the volatile fatty acid mixture in the rumen content of the R calves were high (69 (SE 4.2) \% and 6 (SE 1.7) \% respectively, $n 7$ ) and the relative amount of propionate (the main gluconeogenic precursor) was low (19 (SE 1.9) \%,n 7), it was calculated, with the assumptions of Vermorel (1978), that the contribution of glucose (mainly produced by the gluconeogenic process) to total energy supply was less than $23 \%$ for $\mathrm{R}$ calves. 
Table 1. Animal characteristics and metabolic variables at slaughter for preruminant $(P R)$ and ruminant $(R)$ calves $\ddagger$

(Mean values with their standard errors for seven calves per group)

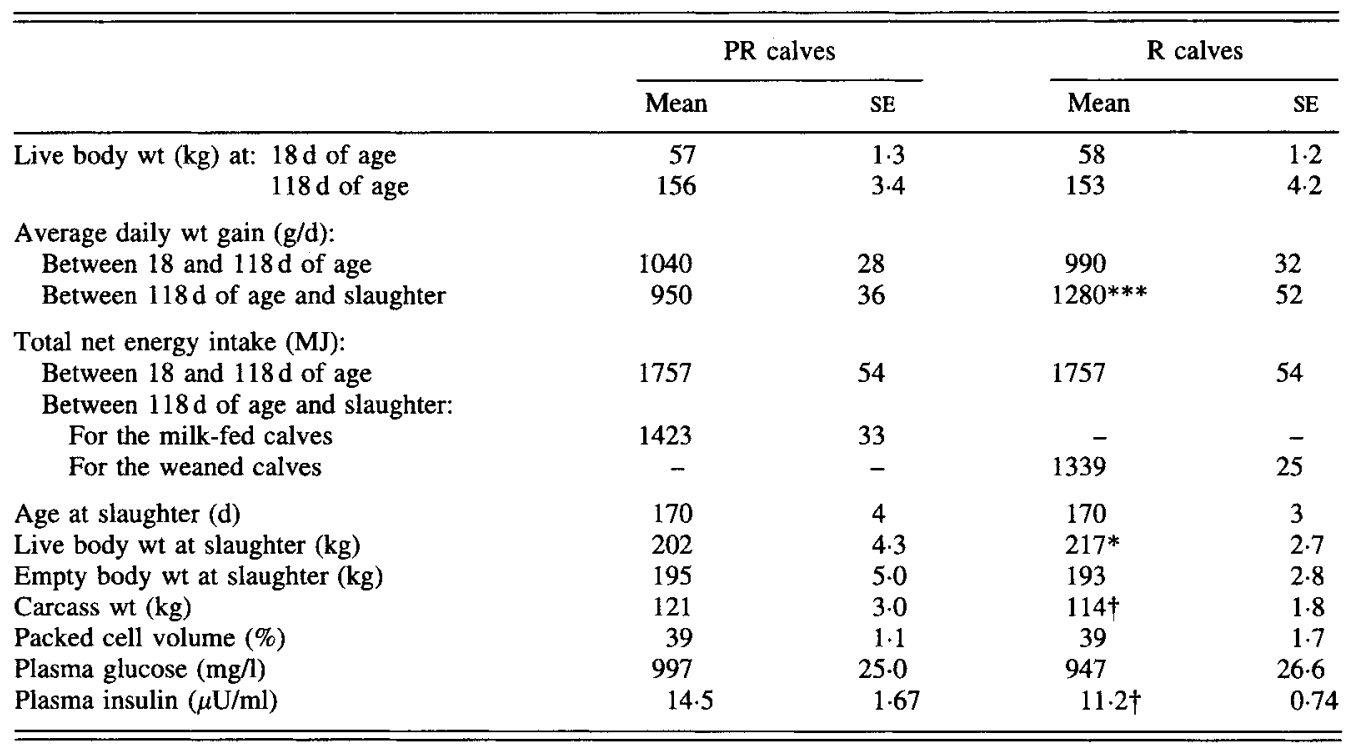

Mean values were significantly different from those for PR calves: $* P<0.05, * * * P<0.001$.

$\dagger$ The difference between mean values for $\mathrm{PR}$ and $\mathrm{R}$ calves showed a tendency towards significance $(P<0 \cdot 10)$.

$\ddagger$ For details of animals and procedures, see pp. 252-253.

As net energy intake from birth onwards, age and empty body weight at slaughter were similar for the two groups (Table 1), only the effects of changes in energy-yielding substrates on glucose transport and glucose transporter expression were studied.

No significant differences between groups were found in packed cell volume or in plasma glucose levels at slaughter, i.e. $16 \mathrm{~h}$ after the last meal. However, the plasma insulin level tended to be lower in $\mathrm{R}$ calves $(-23 \% ; P<0.10)$ which may be related to the high lactose content of the diet of the PR calves.

\section{Muscle metabolic and biochemical characteristics}

Muscle metabolic type was assessed using ICDH and LDH activities, characteristic of oxidative and glycolytic metabolisms respectively (Fig. 1). These two enzyme activities were found to be inversely related in muscles of both PR and $R$ calves, as previously described for the weaned animals (Hocquette et al. 1995). On the basis of these enzyme activities, H, MA and D were classified as oxidative muscles whereas other skeletal muscles from the carcass were considered as oxido-glycolytic. As previously described for the $\mathrm{R}$ calves (Hocquette et al. 1995, 1996b), the most oxidative muscle, $\mathrm{H}$, was characterized by the highest DNA and extractable RNA contents (1939 (SE 31.7) and 607 (SE 62.0) $\mu \mathrm{g} / \mathrm{g}$ wet tissue respectively; $P<0.05$ ). DNA and RNA contents were also higher in the two other oxidative muscles (MA and D) than in mixed or glycolytic skeletal muscles of the carcass (1405-1428 v. 897-1141 $\mu \mathrm{g} / \mathrm{g}$ and $405-413 \nu .234-293 \mu \mathrm{g} / \mathrm{g}$ for DNA and RNA contents respectively; $P<0.05$ ). The most glycolytic muscle was LD for the two groups of calves since it exhibited the highest LDH activity (Fig. 1) and the lowest DNA content. 
A significant effect of calf was demonstrated for metabolic variables (ICDH and LDH activities; $P<0.05$; Fig. 1) but not for biochemical variables (protein, DNA and RNA contents), providing evidence that muscle metabolic type depends largely on physiological characteristics inherent in each animal (genetic, hormonal status, etc.). In addition, ICDH activity in LD from the fourteen calves was positively correlated with ICDH activity in D and MA ( $r 0.66 ; P<0.01)$ and $\mathrm{LDH}$ activity in LD was positively correlated with LDH activities in MA, ST and RA ( $r 0.52,0.61$ and 0.69 respectively; $P<0.05)$. Taken together, these results suggest that some calves are characterized by particularly high (or low) ICDH or LDH activities whichever muscle is studied.

ICDH activity was not different between the two groups of animals except in the MA and LD muscles; ICDH activity was $71 \%$ higher in MA $(P<0.003)$ and $30 \%$ lower
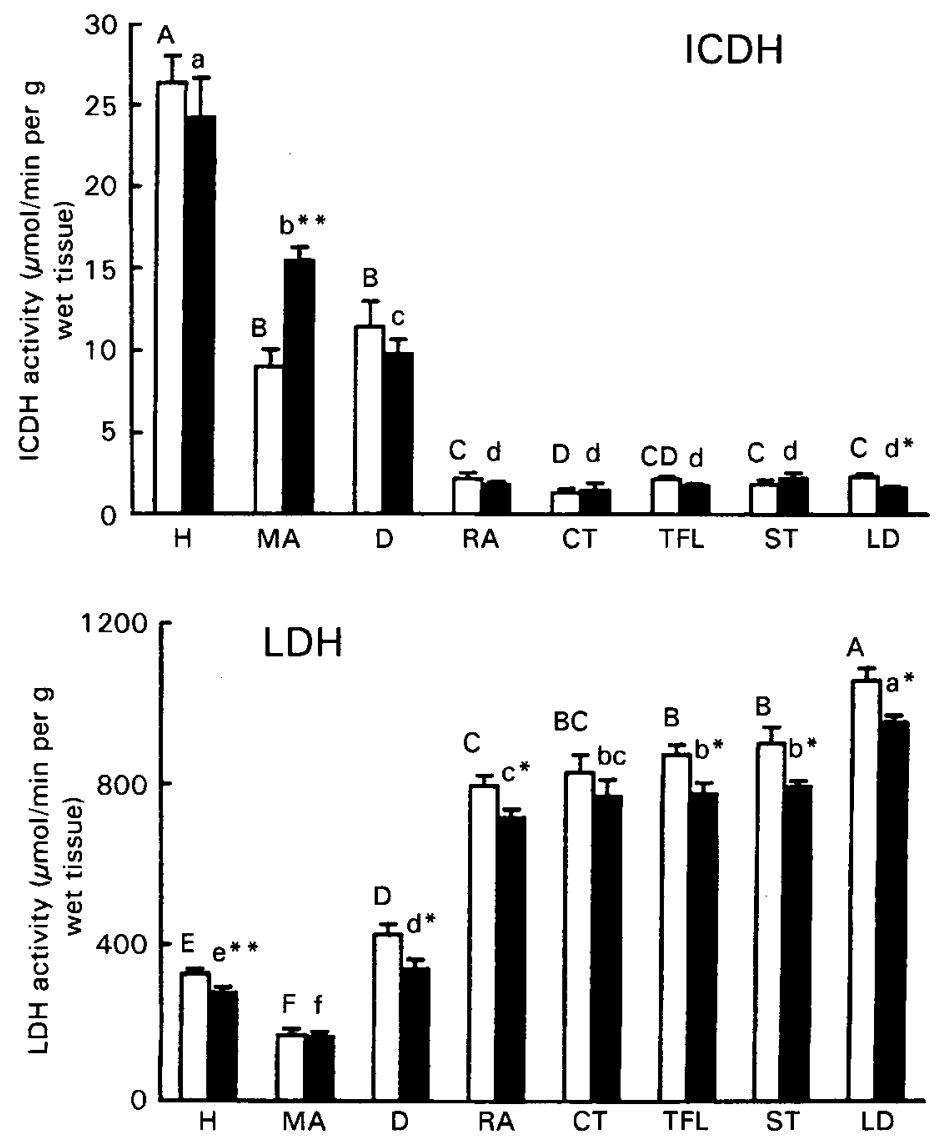

Fig. 1. Isocitrate dehydrogenase ( $E C$ 1.1.1.41; ICDH) and lactate dehydrogenase $(E C$ 1.1.1.27; $\mathrm{LDH})$ activities in heart and various skeletal muscles from preruminant $(P R ; \square)$ and ruminant $(R ; \mathbf{C})$ calves. Enzyme activities were measured spectrophotometrically in tissue homogenates. Values are means with their standard errors for seven animals per group. Significant effects of calf, of muscle and of the group $\times$ muscle interaction were observed for ICDH activity $(P<0.007$, $P<0.0001$ and $P<0.0002$ respectively). Significant effects of group (tested against calves within group), of calf and of muscle were observed for LDH activity $\left(P<0.0025, P<0.014\right.$ and $P<0.0001$ respectively, ${ }^{\mathrm{A}, \mathrm{B}, \mathrm{C}, \mathrm{D}, \mathrm{E}, \mathrm{F}, \mathrm{a}, \mathrm{b}, \mathrm{c}, \mathrm{d}, \mathrm{e}, \mathrm{f}, \mathrm{Means}}$ within a group with different superscript letters were significantly different $(P<0.05)$. Mean values were significantly different from those for PR calves: ${ }^{*} P<0.05,{ }^{* *} P<0.01$. $\mathrm{H}$, heart; MA, masseter; $\mathrm{D}$, diaphragma; RA, rectus abdominis; TFL, tensor fasciae latae; ST, semitendinosus; CT, cutaneous trunci; LD, longissimus dorsi. For details of animals and procedures, see pp. 252-254. 
$(P<0.01)$ in LD from R calves (Fig. 1). LDH activity was slightly lower in oxidative or mixed muscles (except MA and CT) from $\mathrm{R}$ calves (from -10 to $-21 \% ; P<0.05$; Fig. 1). Total DNA content was lower in muscles from $\mathrm{R}$ calves (from $-0.7 \%$ in $\mathrm{MA}$ to $-6.3 \%$ in ST muscles; $P<0.05$; data not shown). In contrast, RNA contents did not differ between the two groups of animals except in the MA and CT muscles: RNA content was $23 \%$ higher in MA $(P<0.05)$ and $17 \%$ lower $(P<0.05)$ in CT from R calves (data not shown).

\section{Rate of glucose transport into muscle}

GTR into incubated muscle-fibre strips was measured as previously described (Hocquette et al. 1995) for RA muscle only, since it is not possible to isolate and incubate properly muscle-fibre strips from other muscles (Hocquette et al. 1995). Basal and maximallyinsulin-stimulated GTR per $\mathrm{g}$ tissue wet weight were 31 and $41 \%$ higher respectively for $\mathrm{R}$ than for PR calves $(P<0.001$; Table 2). Moreover, the stimulation of GTR by insulin was significantly lower in PR calves than in $\mathrm{R}$ animals $(+210 v .+326 \mathrm{nmol} / 20 \mathrm{~min}$ per $\mathrm{g}$ tissue wet weight, i.e. $+70 v$. $+83 \%$ over basal GTR; $P<0.005$; Table 2 ). Data were also expressed per mg DNA or protein assuming that equal concentrations of DNA or protein reflect the same number of multinucleated muscle cells. Similar significant differences were observed regardless of the method of expression of the results (Table 2). A significant effect of calf was demonstrated for GTR, especially when results were expressed per $\mathrm{mg}$ protein (Table 2), indicating that glucose uptake potential by the muscle tissues varies greatly among individuals. Most of the intracellular 2-deoxyglucose transported into bovine muscle (more than $90 \%$ ) was phosphorylated for both PR and R calves (Table 2) suggesting that hexokinase ( $E C$ 2.7.1.1) activity was not rate-limiting. However, when GTR was increased from the lowest value (basal GTR for PR calves) to the highest one (stimulated GTR for $\mathrm{R}$ calves), the relative amount of 2-deoxyglucose which was phosphorylated decreased from 94.0 to $90.8 \%(P<0.05$; Table 2$)$. In addition, values for basal or stimulated GTR were negatively correlated with the proportion of phosphorylated 2-deoxyglucose $(r-0.45 ; n 26 ; P<0.05)$. This might indicate that glucose transport tended to become no longer rate-limiting at the highest GTR.

\section{GLUT4 protein contents and mRNA levels in muscles from preruminant and weaned calves}

In order to identify the molecular mechanisms which could explain the higher basal and insulin-stimulated GTR in R calves, we assessed GLUT4 amount in muscle tissues. Our previous studies have shown that the detection and, therefore, the quantification of GLUT4 in whole homogenates or Triton extracts of muscles was difficult because non-specific bands could appear which correspond to the binding of the primary antibody to major proteins (myosin, actin; Hocquette et al. 1996a,b). Moreover, we also showed that the total content of GLUT4 protein in oxidative muscles was harder to measure using Triton extracts because of its scarcity (Hocquette $e t$ al. 1995). Consequently, it was necessary to prepare crude membranes to be sure of detecting possible alterations in the abundance of GLUT4 in muscles between PR and $R$ calves. Protein yields from crude membrane preparations per $\mathrm{g}$ tissue wet weight or relative to total protein content in homogenates did not differ between $P R$ and $R$ calves but were higher in oxidative (H, MA) than in glycolytic muscles (e.g. RA; Table 3). However, when expressed relative to DNA contents, protein yields from crude membrane preparations did not differ between muscles (Table 3). 


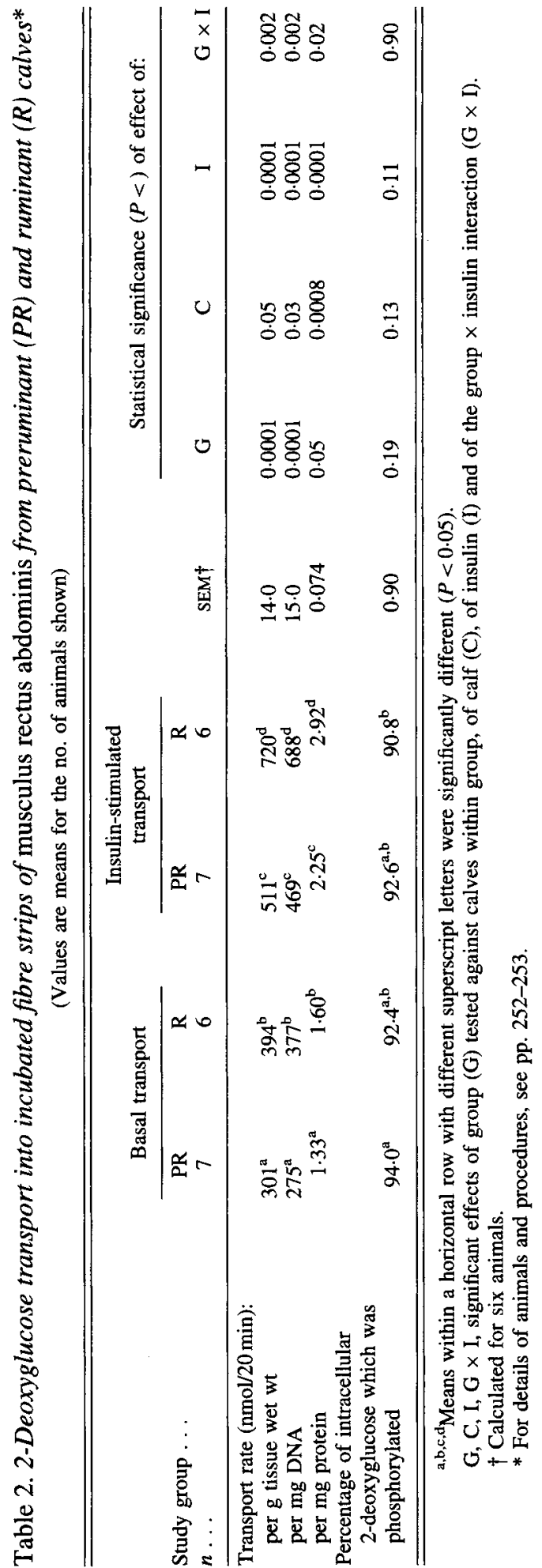


As shown in a representative experiment (Fig. 2(A)), the amount of GLUT4 in crude membranes from RA muscle did not differ significantly between PR and R calves (1.00 (SE 0.210 ) and 1.25 (SE 0.289 ) arbitrary densitometric units respectively). Similar results were observed in $\mathrm{H}$ (1.00 (SE 0.091) and 0.87 (SE 0.087) units in PR and R calves respectively) and in TFL muscle (1.00 (SE 0.059) and 0.89 (SE 0.107) units respectively). In contrast, the amount of GLUT4 was $74 \%$ higher in crude membranes from MA in R calves than in PR calves $(P<0.05$; Fig. $2(\mathrm{~B}))$.

GLUT4 mRNA levels were assessed using a species-specific probe as previously described (Hocquette et al. 1996b). GLUT4 mRNA levels were similar for PR and R calves in H, D, RA, ST and MA muscles (Table 4), although GLUT4 protein content was higher in MA from $R$ calves.

\section{Adipose tissue biochemical characteristics}

Four adipose tissues were also studied in both $\mathrm{PR}$ and $\mathrm{R}$ calves. Biochemical variables varied greatly among adipose tissues $(P<0.0001$; Table 5$)$. DNA contents were lower in internal adipose tissues (541 (SE 51.7) and 377 (SE 51.1) $\mu \mathrm{g} / \mathrm{g}$ tissue wet weight for PAT and OAT respectively) than in peripheral adipose tissues (856 (SE 58.8) and 694 (SE 38.2) $\mu \mathrm{g} / \mathrm{g}$ tissue wet weight for IMAT and SCAT respectively). The highest protein content was observed for SCAT (28.5 (SE 3.56) v. 10.4-15.9 mg/g tissue wet weight for other tissues). Protein yields ( $\mathrm{mg} / \mathrm{g}$ tissue wet weight) from crude membrane preparations were the highest in PAT (1.98 (SE 0.219)) and the lowest in IMAT (0.32 (SE 0.042)) when compared with other adipose tissues $(0.63-0.78)$. When expressed relative to total protein content in crude homogenates, protein yields from crude membrane preparations were, in decreasing order: PAT (13.0 (SE 1.30) \%), OAT (6.1 (SE 0.68) \%), peripheral adipose tissues (3.6 (SE 0.62 ) and 2.7 (SE 0.29) \% for IMAT and SCAT respectively).

In addition, differences were also observed between PR and $R$ calves: protein content in homogenates tended to be higher for internal adipose tissues from the $\mathrm{R}$ group whereas DNA contents tended to be higher for OAT and SCAT from R calves (Table 5). All these differences are likely to be explained by differences in adipocyte sizes between adipose tissues and groups of animals since total DNA and protein in homogenates on a per $\mathrm{g}$ tissue wet weight basis were shown to be decreased in obesity (Pénicaud et al. 1991; FabresMachado \& Saito, 1995) as adipocytes became larger.

Finally, in contrast to observations in muscles, a significant effect of calf was also demonstrated for all these biochemical variables, providing evidence that fat deposition in adipocytes was largely determined by animal characteristics.

\section{GLUT4 protein contents in adipose tissues}

As shown in a representative autoradiogram (Fig. 3(A)), GLUT4 content assessed by Western-blot experiment in whole-tissue homogenates was, in decreasing order: (1) PAT, (2) OAT and IMAT, (3) SCAT. Similar results were observed when crude membranes were used: the mean levels of GLUT4 protein relative to that for OAT were 1.50 (SE 0.209), 1.00 (SE 0.098), 0.85 (SE 0.191), 0.18 (SE 0.028) arbitrary densitometric units for PAT, OAT, IMAT and SCAT respectively. In addition, GLUT4 concentration was higher in crude membranes than in homogenates, and even undetectable in homogenates from SCAT (Fig. 3(A)). Finally, GLUT4 was undetectable in the first pellet and the supernatant fraction discarded during preparation of crude membranes (data not shown). These results indicate that GLUT4 protein content in crude membranes is representative of total GLUT4 protein 


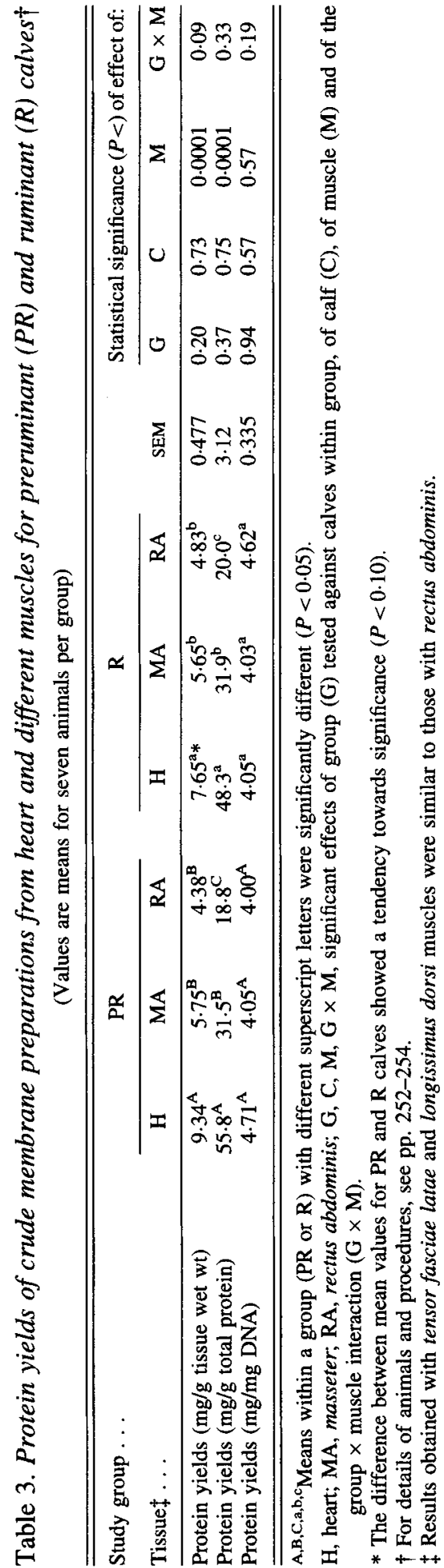


(A)

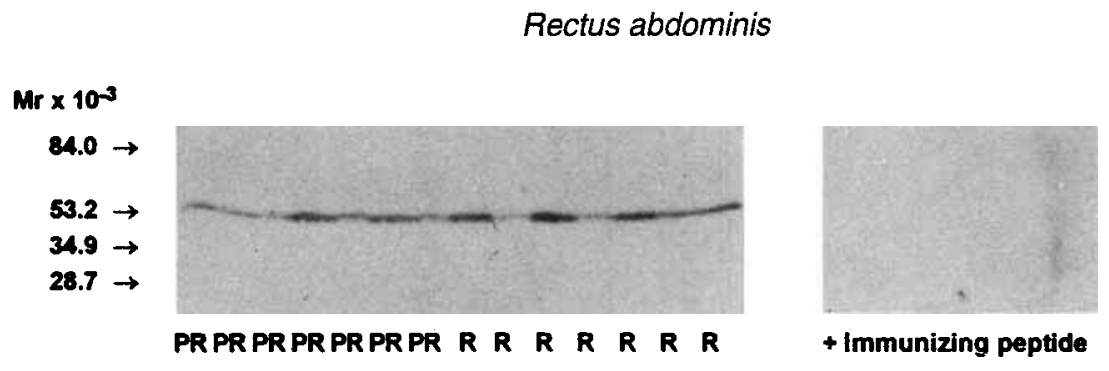

(B)

\section{Masseter}

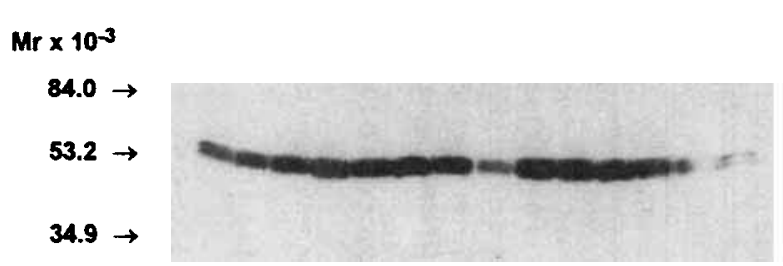

PR PR R R R PR PRPR R R R R PR PR

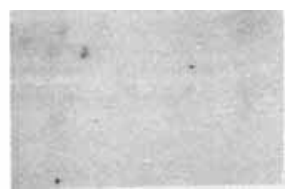

Non-immune serum

Fig. 2. Western-blot analyses of glucose transporter (GLUT4) protein in crude membranes of muscles from preruminant $(P R)$ and ruminant (R) calves. Tissue samples were homogenized in sucrose buffer containing peptidase inhibitors and crude membranes were prepared by differential centrifugation. Different Western-blot experiments were done with equal amounts of protein for each sample (50-100 $\mu \mathrm{g}$ depending on the experiment) and using the highly-sensitive enhanced chemiluminescence system. Representative autoradiograms are shown for rectus abdominis (A) and masseter (B) muscles. Control autoradiograms were overexposed compared with the representative autoradiograms to check the absence of the specific immunoreactive bands by pre-absorbing the primary antibody with the immunizing peptide ( + immunizing peptide) or with a non-immune serum. $\rightarrow$, The position of relative molecular mass $\left(\mathrm{M}_{\mathrm{r}}\right)$ standards. For details of animals and procedures, see pp. 252-254.

in homogenates, as previously described for rodents (Fabres-Machado \& Saito, 1995). It seemed to us, therefore, more appropriate to use membranes rather than homogenates to be sure of detecting any possible alterations in the abundance of GLUT4 between PR and R calves. However, since the amount of GLUT4 depends on the basis on which it is expressed, i.e. per cell or per cell surface area (Fabres-Machado \& Saito, 1995), GLUT4 protein contents were expressed in different ways to take into account variations in protein or DNA contents and in protein yields from crude membrane preparations among animals, adipose tissues and groups of calves (Table 5).

Regardless of the method of expression of the results, GLUT4 protein content relative to that in OAT was the highest in PAT and the lowest in SCAT (Table 5). The mean GLUT4 protein content in all the calves was in decreasing order: PAT, OAT, IMAT and SCAT $(P<0.05)$ when the results were expressed per $\mathrm{mg}$ total protein in homogenates (3.24 (SE 0.517), 1.00 (SE 0.081), 0.43 (SE 0.056), 0.09 (SE 0.014) units respectively) or per $\mathrm{g}$ tissue wet weight (4.75 (SE 0.681), 1.00 (SE 0.103), 0.41 (SE 0.077), 0.25 (SE 0.052) units respectively). However, when the results were expressed per mg DNA, the mean GLUT4 protein content in IMAT (0.17 (SE 0.033) units) was as low as that in SCAT $(0.12$ (SE 
Table 4. Relative levels between preruminant $(P R)$ and ruminant $(R)$ calves of glucose transport protein GLUT4 mRNA in heart and various skeletal muscles*

(Mean values with their standard errors for five to seven calves per group. Northern-blot experiments were done using total RNA to quantify relative levels of GLUT4 mRNA levels between PR and R calves. Values are expressed in arbitrary densitometric units per mg RNA loaded on the gel (relative to the mean value in PR calves). No significant differences were observed between the two groups of animals)

\begin{tabular}{|c|c|c|c|c|c|c|c|c|c|c|}
\hline \multirow[t]{2}{*}{ Muscle ... } & \multicolumn{2}{|c|}{$\mathrm{H}$} & \multicolumn{2}{|c|}{ MA } & \multicolumn{2}{|c|}{ D } & \multicolumn{2}{|c|}{ RA } & \multicolumn{2}{|c|}{ ST } \\
\hline & Mean & SE & Mean & $\mathrm{SE}$ & Mean & SE & Mean & SE & Mean & SE \\
\hline PR calves & 1.00 & 0.148 & 1.00 & 0.269 & 1.00 & 0.171 & 1.00 & 0.061 & 1.00 & 0.229 \\
\hline $\mathrm{R}$ calves & 1.22 & 0.152 & 1.06 & 0.097 & $1 \cdot 14$ & 0.126 & 1.32 & 0.199 & 0.95 & 0.178 \\
\hline
\end{tabular}

H, heart; MA, masseter; D, diaphragma; RA, rectus abdominis; ST, semitendinosus.

* For details of animals and procedures, see pp. 252-255.

0.025) units), but higher in PAT and OAT (3.09 (SE 0.524) and 1.00 (SE 0.132) units respectively).

As shown in a representative experiment for OAT (Fig. 3(B)), GLUT4 protein content per $100 \mu \mathrm{g}$ protein in crude membranes loaded on the gels did not significantly differ between PR and $R$ calves for the four different adipose tissues studied (Table 5). Similar results were observed when the data were expressed per $\mathrm{g}$ tissue wet weight (Table 5). However, mean GLUT4 protein content was lower in R calves than in PR calves $(-39 \%$; $P<0.05$ ) when results were expressed on a per cell basis, i.e. per mg DNA or per $\mathrm{mg}$ protein in homogenates. This difference was apparent in internal adipose tissues and SCAT but not in IMAT (Table 5).

Attempts were made to detect GLUT4 mRNA in adipose tissues in order to quantify relative levels of GLUT4 transcripts between PR and R calves. Unfortunately, GLUT4 mRNA levels were too low to be detected with confidence even by using a species-specific probe as described previously for muscle tissues. Therefore, data on the GLUT4 gene expression in adipose tissues could not be presented.

\section{Differential glycosylation of the GLUT4 protein between muscle and adipose tissues}

Initial Western-blot experiments revealed that the GLUT4 protein from white adipose tissues had a slightly reduced mobility on SDS-PAGE compared with that from bovine skeletal muscle or from rat heart (Fig. 3(C)). The possibility was considered that these different eletrophoretic patterns were due to heterogeneity of glycosylation of the GLUT4 proteins. Therefore, membrane samples were pretreated with endoglycosidase $\mathrm{F}-\mathrm{N}$ glycosidase $F$ before Western-blot experiments. After complete removal of the oligosaccharides, the GLUT4 protein had a reduced apparent molecular weight (approximately $20 \%$ less for adipose tissue and $10 \%$ less for MA) which was identical for the three tissues examined (rat heart and bovine adipose tissues or skeletal muscle; Fig. 3(C)).

\section{DISCUSSION}

\section{Bovine muscle characteristics}

Studies on cattle musculature have concentrated on muscle-fibre-type composition or meatquality variables and generally only one or two muscles have been studied (Picard et al. 1995). Therefore, several muscles were included in the present study to be more confident 
J.-F. HOCQUETTE ET $A L$.

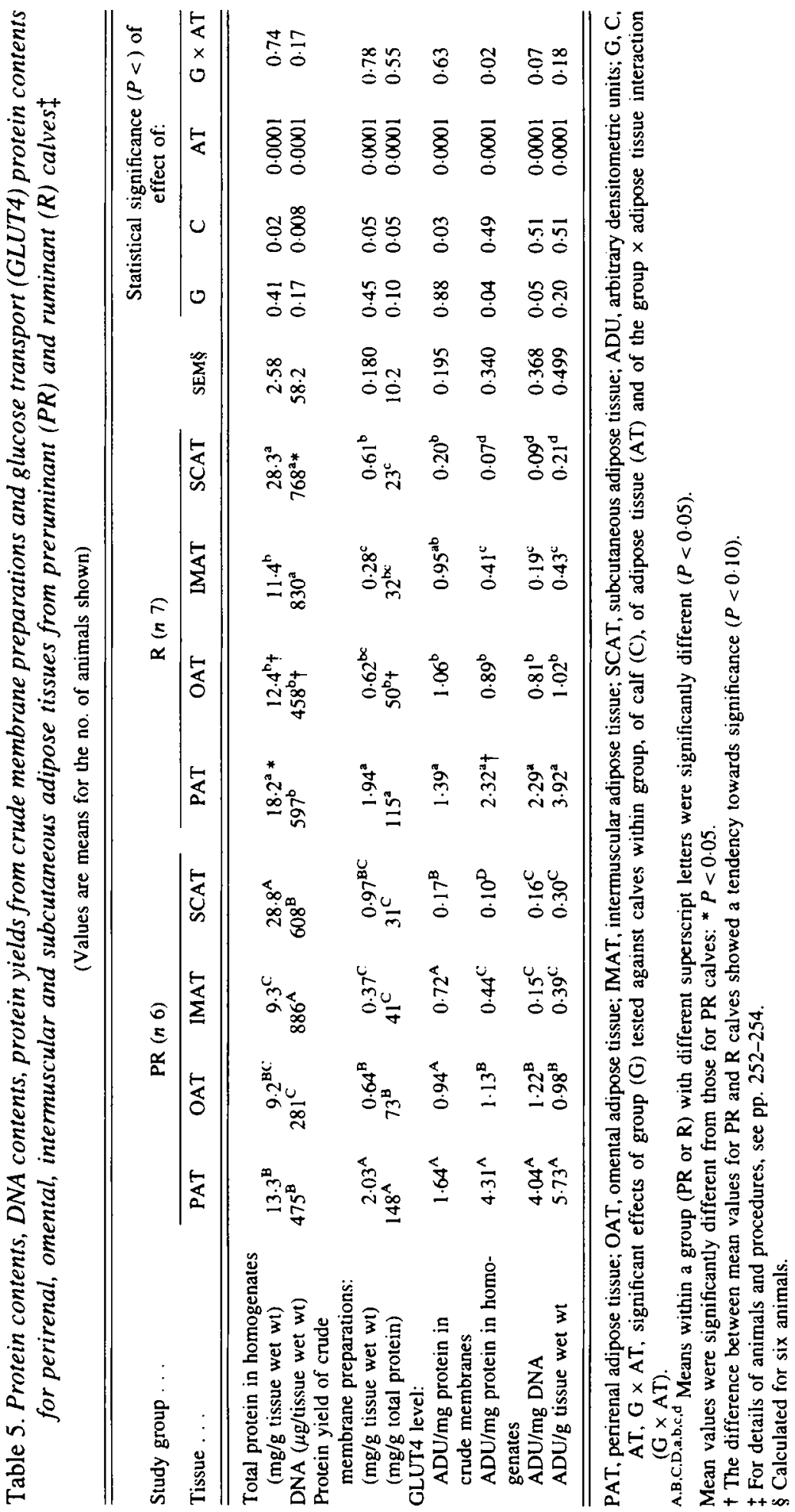


(A)

\section{Adipose tissues}
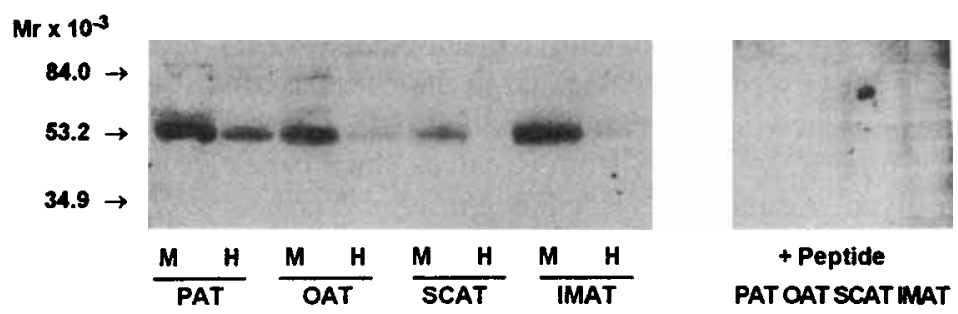

(B)

Omental adipose tissue

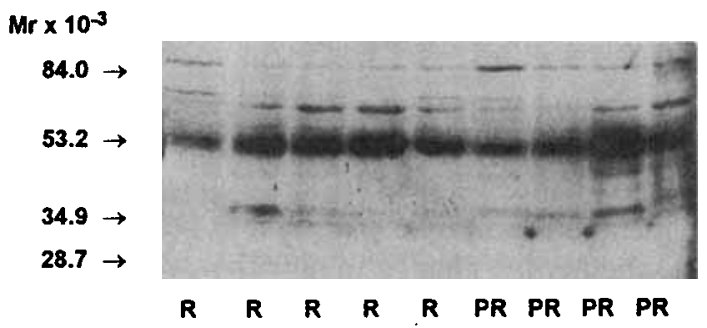

(C)

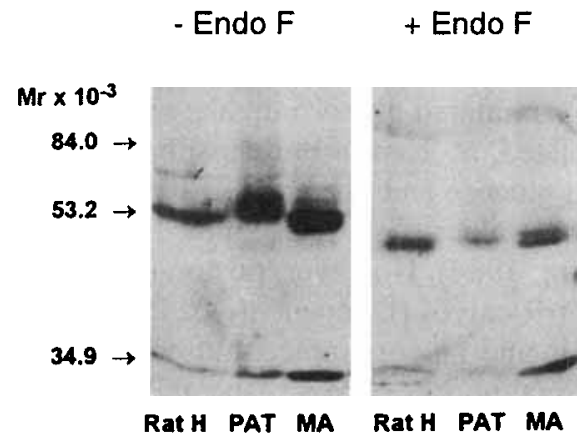

Fig. 3. Western-blot analyses of glucose transporter (GLUT4) protein in bovine adipose tissues. Tissue samples of perirenal (PAT), omental (OAT), intermuscular (IMAT) and subcutaneous (SCAT) adipose tissues were homogenized in sucrose buffer containing peptidase inhibitors and crude membranes were prepared by differential centrifugation. Western-blot experiments were done using the highly-sensitive enhanced chemiluminescence system. $\rightarrow$, The position of relative molecular mass $\left(\mathrm{M}_{\mathrm{r}}\right)$ standards. (A) Analyses were done with $50 \mu \mathrm{g}$ protein from homogenates $(\mathrm{H})$ and $\mathrm{crude}$ membranes $(M)$ from the four adipose tissues. Control autoradiograms were done to check the absence of the specific immunoreactive bands by pre-absorbing the primary antibody with the immunizing peptide (+peptide). (B) Analyses were done with $30 \mu \mathrm{g}$ protein from crude membranes of OAT from preruminant (PR) and ruminant (R) calves. (C) Analyses were done with $30 \mu \mathrm{g}$ crude membranes of bovine masseter muscle $(\mathrm{M})$ and PAT before ( - endo $\mathrm{F})$ and after (+ endo F) deglycosylation by endoglycosidase F-N-glycosidase F. A control sample of rat heart (rat $\mathrm{H}$ ) was added to the experiment. 
of the results and/or to detect any muscle-specific response to changes in nutrition at weaning. The decrease in dietary carbohydrate supply from weaning induced a small, but significant, decrease in LDH activity in almost all studied muscles (Fig. 1). In MA, weaning induces large increases in oxidative metabolism (Fig. 1), probably associated with changes in muscle activity since MA located in the cheek is almost constantly active in $R$ calves for solid food chewing (Karlstrom et al. 1994). These changes might explain the higher content of total RNA in MA from R calves since oxidative muscles contain more total RNA than glycolytic muscles (Hocquette et al. 1996b).

\section{Glucose uptake by bovine muscles}

GTR is considered as the rate-limiting step of glucose metabolism in muscles since intracellular free glucose concentrations are low (Table 2; for review, see Kahn, 1992; Hocquette et al. 1996a). However, when GTR is excessively elevated by either overexpression of GLUT4, exercise, hyperglycaemia or hyperinsulinaemia, free glucose accumulates in the cells (Manchester et al. 1994) and intracellular steps of glucose metabolism other than GTR become rate-limiting (for review, see Zierath, 1995; Hocquette et al. 1996a).

Glucose tolerance was shown to decrease with increasing age, either for PR (Webb et al. 1969; Doppenberg \& Palmquist, 1991) or R (Jarrett et al. 1964; Colvin et al. 1967; Webb et al. 1969) calves or lambs. However, since glucose metabolism is affected by various physiological or metabolic variables (for review, see Kahn, 1992) especially age, it was difficult to conclude whether the change in nutrition which occurs at weaning induces a change in insulin sensitivity in ruminants. Our study addresses this question by measuring in vitro GTR (Hocquette et al. 1995) under conditions where most of the factors influencing glucose uptake were similar except the change in nutrition induced by weaning. This approach lead us to demonstrate (1) that insulin increased GTR in calf RA muscle, but to a lower extent than that in rats or in human subjects (Hocquette et al. 1995) and (2) that maximal response to insulin was lower in PR than in age-matched $R$ calves (Table 2) in agreement with other data in vivo (Palmquist et al. 1992). Thus, these differences in GTR for one muscle are likely to reflect differences in the whole-body response to insulin, since in vivo whole-body insulin-stimulated glucose uptake and in vitro GTR in vastus lateralis muscle are positively correlated, at least in human subjects (Zierath, 1995).

Our findings for plasma glucose and insulin levels $16 \mathrm{~h}$ after the last meal (Table 1) are in agreement with preprandial values observed in milk-fed (Hostettler-Allen et al. 1994) or weaned calves (Kouame et al. 1984). However, postprandial glucose and insulin levels are much higher for PR than for R calves (Doppenberg \& Palmquist, 1991). In vitro GTR was measured at the same insulin and glucose concentrations in the incubation medium. Thus, the higher in vivo glycaemia in PR calves, especially in the postprandial state, may compensate for the lower preprandial GTR by increasing the non-insulin-mediated rate of glucose uptake as in type II diabetic patients (Zierath, 1995).

\section{Regulation of GTR in muscles}

Long-chain fatty acids and carbohydrates supplied by the diet decrease as young calves are weaned, since forage is degraded into volatile fatty acids by micro-organisms present in the rumen after weaning. In contrast, rats change from a high-fat diet to a high-carbohydrate diet during the suckling-weaning transition. These changes in the rat were shown to be associated with an increase in insulin responsiveness of glucose uptake by muscles (for 
review, see Girard et al. 1992). In vivo experiments 4 h post feeding (Palmquist et al. 1992) and in vitro studies in the preprandial state (Table 2) indicate that a similar change occurs in the calf despite great differences between species in the changes of nutrition at weaning. However, unlike the rat (for review, see Girard et al. 1992), GLUT4 protein content did not increase in adipose tissues and muscles from the weaned calf except in MA muscle. This clearly demonstrates (1) that the regulation of GTR is under species- and muscle-specific control mechanisms and (2) that GLUT4 expression is poorly regulated at weaning in the calf despite profound changes in nutrition.

The low ability of insulin to stimulate GTR in PR calves in the preprandial state (Table 2) was shown to be exaggerated after feed consumption (Hostettler-Allen et al. 1994), providing evidence for the involvement of nutritional factors. The high amount of fat in the milk-substitute might induce an insulin resistance as shown in the rat (Girard et al. 1992). However, this seems unlikely since the dietary fat content did not modify the action of insulin on glucose metabolism in veal calves (Palmquist et al. 1992). The lactose content of the diet of PR calves, which was particularly high in the present study ( $40 \%$ of energy intake), may decrease the ability of insulin to stimulate glucose uptake by muscles (Palmquist, et al. 1992; for review, see Bauchart et al. 1996) leading to the concept of glucose toxicity (for review, see Yki-Järvinen, 1992; Zierath, 1995). The desensitization of the glucose transport system to insulin by chronic hyperglycaemia can be mediated by an increase in glucose flux through the glucosamine pathway without any change in the amount of GLUT4 (Robinson et al. 1993) as in our calves (Fig. 2). Veal calves intensively fed on milk-substitutes, especially lactose-rich milk-substitutes, develop glucose intolerance and sometimes glycosuria (Palmquist, et al. 1992; Hostettler-Allen et al. 1994; for review, see Bauchart et al. 1996). This may indicate a saturated capacity for glucose use which would be expected to reduce feed efficiency and, therefore, growth performance (Hostettler-Allen et al. 1994).

\section{GLUT4 expression in bovine muscles}

GLUT4 protein content is much higher in oxidative muscles than glycolytic muscles in the rat (for review, see Kahn, 1992) but not in human subjects (Andersen et al. 1993a; Houmard et al. 1995) and in ruminant species (Hocquette et al. 1995). This may be related to species-specific muscle characteristics rather than to muscle metabolism itself since, in contrast to rodents, the fibre-type composition of the major muscle groups of human subjects (Johnson et al. 1973) and bovines (except H and MA; Karlstrom et al. 1994) differs relatively little among different muscle groups. Difference in physical activity may also influence GLUT4 protein content, as shown in rats (Etgen et al. 1993; Megeney et al. 1993) and in human subjects (Houmard et al. 1995). Therefore, it is not surprising that, in ruminants, active locomotor mixed muscles (LD, TFL, ST) contain a relatively high amount of GLUT4 (Hocquette et al. 1995). The higher GLUT4 content in the weaned calf only in MA muscle (Fig. 2(B)) results from a specific change in the physiological function of this muscle (the development of food chewing).

Although GLUT4 was initially known to be regulated at the pretranslational level, especially in adipose tissues (for review, see Klip et al. 1994; McGowan et al. 1995), it is now accepted that GLUT4 expression may be achieved by modulating the translation efficiency or the protein turnover (Tordjman et al. 1990; Hocquette et al. 1996b; for review, see Klip et al. 1994). The small increase in the amount of GLUT4 protein in MA at weaning (Fig. 2(B)) with no significant difference in GLUT4 mRNA levels (Table 4) suggests the existence of a translational or post-translational mechanism of GLUT4 
regulation, as in muscles from glucose-infused rats (Klip et al. 1994) or from human subjects after $4 \mathrm{~h}$ of hyperinsulinaemia (Anderson et al. 1993a,b).

\section{Biochemical variables and GLUT4 protein content of adipose tissues}

Total protein and DNA contents per $\mathrm{g}$ tissue wet weight were reduced in white adipose tissues of obese animals in which size of adipocytes was increased (Pénicaud et al. 1991; Fabres-Machado \& Saito, 1995). Thus, our results (Table 5) suggest that adipocytes were larger in PR than in $R$ calves and also larger in internal adipose tissues (OAT and PAT) than in peripheral adipose tissues (IMAT and SCAT), as previously described (Robelin, 1986; De la Hoz \& Vernon, 1993). This is the reason why it is preferable to express GLUT4 content per mg DNA or per mg total protein, i.e. on a per cell basis.

Unlike in rats, acetate rather than glucose is the major precursor for fatty acid synthesis in ruminants, but glucose is required for lipogenesis since it is a precursor for acylglycerolglycerol and the major source for NADPH (Smith, 1983). The lower GLUT4 content in peripheral adipose tissue compared with internal adipose tissues is in agreement with the low ability of insulin to stimulate GTR in isolated adipocytes from ovine SCAT (Sasaki, 1990) and with insulin resistance in peripheral adipose tissues compared with OAT (De la Hoz \& Vernon, 1993). Similar differences in GLUT4 contents were observed between rat peripheral and internal adipose tissues (Cousin et al. 1993).

The lower GLUT4 content on a per cell basis in $\mathrm{R}$ calves (Table 5) suggests that glucose uptake by adipose tissues may be lower in $\mathrm{R}$ calves than in PR calves, whereas GTR was enhanced in RA muscle from R calves (Table 2). In contrast, a 5-fold increase in GLUT4 content was observed in rat adipose cells at weaning (for review, see Girard et al. 1992). These differences among species are likely to be explained by differential variations in insulinaemia; the low insulin level in the weaned calf was associated with a decrease in GLUT4 content whereas the high blood insulin levels in the weaned rat (Girard et al. 1992) and in the hyperinsulinaemic obese mouse (Fabres-Machado \& Saito, 1995) were associated with increases in GLUT4 content per cell.

Characterization of a GLUT4-like protein in ruminant tissues has been performed by several authors and some conflicting results were observed in relation to its apparent molecular weight (Hocquette et al. 1996b). Some of these discrepancies may be explained by a higher molecular weight of the GLUT4 protein in adipose tissues (Fig. 3(C)), as previously observed in the mouse (Le Marchand-Brustel et al. 1990). This was shown to be due to a differential glycosylation of the GLUT4 protein (Fig. 3(C)). Such an heterogeneity of glycosylation has been previously observed within the same tissue in mice (Kaestner $e t$ al. 1991). An altered glycosylation may affect glucose transporter function and, in some cases, gene expression as has been shown for GLUT1; inhibitors of glycosylation induced an enhanced GLUT1 mRNA and protein expression but did not increase GTR, suggesting that the deglycosylated form of GLUT1 is less functional (Maher \& Harrison, 1991).

\section{Large inter-individual variability of metabolic and biochemical variables}

The statistical analysis allowed us to test the effect of animal for all variables studied. In muscles, no significant effect was demonstrated for protein, DNA and RNA contents, suggesting that the muscle structure did not differ between animals. On the contrary, for adipose tissues, there were highly significant differences between animals for DNA and protein contents and for protein yields from crude membrane preparations (Table 5). This 
may be due to great differences in adipocyte size among animals which itself depends on the amount of triacylglycerols stored within each adipocyte.

All metabolic variables examined in muscles (ICDH and LDH activities as well as GTR) varied greatly among calves (Fig. 1 and Table 2) as in steers for muscle enzyme activities (Karlstrom et al. 1994) and in human subjects for fibre-type proportion (Johnson et al. 1973), GLUT4 content and GTR (for review, see Zierath, 1995). This large interindividual variability in muscle metabolism is dependent, at least in part, on genetic inheritance and, to some extent, physical activity, at least in human subjects (for review, see Zierath, 1995).

In conclusion, in the case of prolongation of milk-feeding, especially with lactose-rich milk-substitutes for veal calf production (Hostettler-Allen et al. 1994), PR calves seem to be less sensitive to insulin than age-matched weaned calves both in vivo (Palmquist et al. 1992) and in vitro as shown in the present study. In contrast to the situation in suckling and weaned rats (for review, see Girard, 1992), GLUT4 amount was approximately the same in skeletal muscles from PR or R calves except in MA muscle which is more oxidative and more active after weaning. Finally, unlike the rat, GLUT4 protein expressed on a per cell basis is lower in adipose tissues in the weaned calf, in agreement with concomitant variations in insulin levels.

We gratefully acknowledge Dr Armelle Leturque (CNRS, Meudon, France) for initial advice, Dr Dominique Dardevet and Dr Yves Geay (INRA, Theix, France) for helpful discussions. We also thank Nicole Guivier, Nathalie Depoortere, Florent Bornes and Sylvie Toilon for their contribution, Robert Jailler, Francis Sauvage, Sylvie Chassagnette and their colleagues for the management of the animals and Gilbert Cuylle and his group for the management of the slaughterhouse.

\section{REFERENCES}

Andersen, P. H., Lund, S., Schmitz, O., Junker, S., Kahn, B. B. \& Pedersen, O. (1993a). Increased insulinstimulated glucose uptake in athletes - the importance of GLUT4 mRNA, GLUT4 protein and fibre type composition of skeletal muscle. Acta Physiologica Scandinavica 149, 393-404.

Andersen, P. H., Lund, S., Vestergaard, H., Junker, S., Kahn, B. B. \& Pedersen, O. (1993b). Expression of the major insulin regulatable glucose transporter (GLUT4) in skeletal muscle of non-insulin-dependent diabetic patients and healthy subjects before and after insulin infusion. Journal of Clinical Endocrinology and Metabolism 77, 27-32.

Bauchart, D., Ortigues, I., Hocquette, J. F., Gruffat, D. \& Durand, D. (1996). Energy and fat metabolism of the liver, the digestive tract and muscles: transport, processing, energy consumption, fixation by tissues. In Veal, Perspectives to the Year 2000, Proceedings of the International Symposium, Le Mans, France, pp. 255-290 [The French Federation of Veal Producers, editor]. Le Mans: Presse de Jouve.

Colvin, H. W. Jr, Attebery, J. T. \& Daniels, L. B. (1967). Effect of diet on glucose tolerance of dairy calves one to thirteen weeks old. Journal of Dairy Science 50, 362-370.

Cousin, B., Casteilla, L., Dani, C., Muzzin, P., Revelli, J. P. \& Pénicaud, L. (1993). Adipose tissues from various anatomical sites are characterized by different patterns of gene expression and regulation. Biochemical Journal 292, 873-876.

De la Hoz, L. \& Vernon, R. G. (1993). Endocrine control of sheep adipose tissue fatty acid synthesis - depot specific differences in response to lactation. Hormone and Metabolic Research 25, 214-218.

Doppenberg, J. \& Palmquist, D. L. (1991). Effect of dietary fat level on feed intake, growth, plasma metabolites and hormones of calves fed dry or liquid diets. Livestock Production Science 29, 151-166.

Etgen, G. J., Brozinick, J. T., Kang, H. Y. \& Ivy, J. L. (1993). Effects of exercise training on skeletal muscle glucose uptake and transport. American Journal of Physiology 264, C727-C733.

Fabres-Machado, U. \& Saito, M. (1995). The effect of adipose cell size on the measurement of GLUT4 in white adipose tissue of obese mice. Brazilian Journal of Medical and Biological Research 28, 369-376. 
Girard, J., Ferré, P., Pégorier, J. P. \& Duée, P. H. (1992). Adaptations of glucose and fatty acid metabolism during perinatal period and suckling-weaning transition. Physiological Reviews 72, 507-562.

Hocquette, J. F., Balage, M. \& Ferré, P. (1996a). Facilitative glucose transporters in ruminants. Proceedings of the Nutrition Society 55, 221-236.

Hocquette, J. F., Bornes, F., Balage, M. Ferré, P., Grizard, J. \& Vermorel, M. (1995). Glucose-transporter (GLUT4) protein content in oxidative and glycolytic skeletal muscles from calf and goat. Biochemical Journal $305,465-470$.

Hocquette, J. F., Graulet, B., Castiglia-Delavaud, C., Bornes, F., Lepetit, N. \& Ferré, P. (1996b). Insulinsensitive glucose transporter transcript levels in calf muscles assessed with a bovine GLUT4 cDNA fragment. International Journal of Biochemistry and Cell Biology 28, 795-806.

Hostettler-Allen, R. L., Tappy, L. \& Blum, J. W. (1994). Insulin resistance, hyperglycemia, and glucosuria in intensively milk-fed calves. Journal of Animal Science 72, 160-173.

Houmard, J. A., Weidner, M. D., Dolan, P. L., Leggett-Frazier, N., Gavigan, K. E., Rickey, M. S., Tyndall, G. E., Zhen, D. H., Alshami, A. \& Dohm, G. L. (1995). Skeletal muscle GLUT4 protein concentration and aging in humans. Diabetes $44,555-560$.

Jarrett, I. G., Jones, G. B. \& Potter, B. J. (1964). Changes in glucose utilization during development of the lamb. Biochemical Journal 90, 189-194.

Johnson, M. A., Polgar, J., Weightman, D. \& Appleton, D. (1973). Data on the distribution of fibre types in thirty-six human muscles. An autopsy study. Journal of Neurology Science 18, 111-129.

Jouany, J. P. (1982). Volatile fatty acid and alcohol determination in digestive contents, silage, juices, bacterial cultures and anaerobic fermentor contents. Science des Aliments 2, 131-144.

Kaestner, K. H., Flores-Riveros, J. R., McLenithan, J. C., Janicot, M. \& Lane, D. (1991). Transcriptional repression of the mouse insulin-responsive glucose transporter (GLUT4) gene by cAMP. Proceedings of the National Academy of Sciences USA 88, 1933-1937.

Kahn, B. B. (1992). Facilitative glucose transporters - regulatory mechanisms and dysregulation in diabetes. Journal of Clinical Investigation 89, 1367-1374.

Karlstrom, K., Essen-Gustavsson, B. \& Lindholm, A. (1994). Fibre type distribution, capillarization and enzymatic profile of locomotor and nonlocomotor muscles of horses and steers. Acta Anatomica 151, 97-106.

Klip, A., Tsakiridis, T., Marette, A. \& Ortiz, P. A. (1994). Regulation of expression of glucose transporters by glucose - A review of studies in vivo and in cell cultures. FASEB Journal 8, 43-53.

Kouame, K. G., Troccon, J. L., Patureau-Mirand, P., Journet, M. \& Pion, R. (1984). Nutrition des veaux au cours du sevrage. I. Evolution de la consommation d'aliments et des concentrations sanguines de divers métabolites énergétiques (Calf nutrition during the weaning period. I. Variations in feed intake and blood levels of energy metabolites). Annales de Zootechnie 33, 427-444.

Le Marchand-Brustel, Y., Olichon-Berthe, C., Grémaux, T., Tanti, J. F., Rochet, N. \& Van Obberghen, E. (1990). Glucose transport in insulin sensitive tissues of lean and obese mice. Effect of the thermogenic agent BRL 26830A. Endocrinology 127, 2687-2695.

McGowan, K. M., Long, S. D. \& Pekala, P. H. (1995). Glucose transporter gene expression: regulation of transcription and mRNA stability. Pharmacology and Therapeutics 66, 465505.

Maher, F. \& Harrison, L. C. (1991). Stimulation of glucose transporter (GLUT1) mRNA and protein expression by inhibitors of glycosylation. Biochimica et Biophysica Acta 1089, 27-32.

Manchester, J., Kong, X., Nerbonne, J., Lowry, O. H. \& Lawrence, J. C. Jr (1994). Glucose transport and phosphorylation in single cardiac myocytes: rate-limiting steps in glucose metabolism. American Journal of Physiology 266, E326-E333.

Megeney, L. A., Neufer, P. D., Dohm, G. L., Tan, M. H., Blewett, C. A., Elder, G. C. B. \& Bonen, A. (1993). Effects of muscle activity and fibre composition on glucose transport and GLUT4. American Journal of Physiology 264, E583-E593.

Palmquist, D. L., Doppenberg, J. D., Roehrig, K. L. \& Kinsey, D. J. (1992). Glucose and insulin metabolism in ruminating and veal calves fed high and low fat diets. Domestic Animal Endocrinology 9, 233-241.

Pénicaud, L., Ferré, P., Assimacopoulos-Jeannet, F., Perdereau, D., Leturque, A., Jeanrenaud, B., Picon, L. \& Girard, J. (1991). Increased gene expression of lipogenic enzymes and glucose transporter in white adipose tissue of suckling and weaned obese Zucker rats. Biochemical Journal 279, 303-308.

Picard, B., Gagniere, H., Geay, Y., Hocquette, J. F. \& Robelin, J. (1995). Study of the influence of age and weaning on the contractile and metabolic characteristics of bovine muscle. Reproduction Nutrition Development 35, 71-84.

Robelin, J. (1986). Growth of adipose tissues in cattle; partitioning between depots, chemical composition and cellularity. A review. Livestock Production Science 14, 349-364.

Robinson, K. A., Sens, D. A. \& Buse, M. G. (1993). Pre-exposure to glucosamine induces insulin resistance of glucose transport and glycogen synthesis in isolated rat skeletal muscles - study of mechanisms in muscle and in rat-1 fibroblasts overexpressing the human insulin receptor. Diabetes 42, 1333-1346.

Sasaki, S. (1990). Mechanism of insulin resistance in the post receptor events in sheep: 3-O-methylglucose transport in ovine adipocytes. Hormone and Metabolic Research 22, 457-461. 
Smith, S. B. (1983). Contribution of the pentose cycle to lipogenesis in bovine adipose tissue. Archives of Biochemistry and Biophysics 221, 46-56.

Statistical Analysis Systems (1987). SAS/STAT ${ }^{\circledR}$ Guide for Personal Computers. Version 6. Cary, NC: SAS Institute Inc.

Tordjman, K. M., Leingang, K. A. \& Mueckler, M. (1990). Differential regulation of the HepG2 and adipocyte/ muscle glucose transporters in 3T3L1 adipocytes - effect of chronic glucose deprivation. Biochemical Journal 271, 201-207.

Vermorel, M. (1978). Energie (Energy). In Alimentation des Ruminants, pp. 47-88 [R. Jarrige, editor]. Versailles, France: INRA Publications.

Webb, D. W., Head, H. H. \& Wilcox, C. J. (1969). Effect of age and diet on fasting blood and plasma glucose levels, plasma nonesterified fatty acid levels, and glucose tolerance in dairy calves. Journal of Dairy Science 52, 2007-2013.

Yki-Järvinen, H. (1992). Glucose toxicity. Endocrine Reviews 13, 415-431.

Zierath, J. R. (1995). In vitro studies of human skeletal muscle: hormonal and metabolic regulation of glucose transport introduction. Acta Physiologica Scandinavica 155, 11-96. 